\title{
FREQUENCY OF INTESTINAL PARASITES IN PATIENTS ATTENDED AT A UNIVERSITARY HOSPITAL IN MACEIÓ, STATE OF ALAGOAS, BRAZIL
}

\author{
FREQUENNCIA DE PARASITOS INTESTINAIS EM PACIENTES ATENDIDOS EM \\ UM HOSPITAL UNIVERSITÁRIO EM MACEIÓ, ESTADO DE ALAGOAS, BRASIL
}

\author{
José Rayron Oliveira de ARAÚJO' ${ }^{1}$; Ramon Manoel Sabino CAVALCANTE ${ }^{1}$; \\ Antônio de Pádua Medeiros de CARVALHO NETO' ${ }^{1}$; Karwhory Wallas Lins da SILVA ${ }^{1}$; \\ Sandra Regina Guimarães SILVA ${ }^{1}$; José Rodrigo da Silva FERREIRA ${ }^{3}$; \\ Marília Gabriela dos Santos CAVALCANTI ${ }^{2}$; Thiago José MATOS-ROCHA ${ }^{1,2^{*}}$ \\ 1. Centro Universitário Cesmac, Maceió, AL, Brasil. tmatosrocha@cesmac.edu.br*. 2. Universidade Estadual de Ciências da Saúde de \\ Alagoas, Maceió, AL, Brasil. 3. Universidade Federal da Paraíba, João Pessoa, PB, Brasil.
}

\begin{abstract}
The aim of this study was to analyze the parasitological tests of a population at a public hospital in Maceió-AL. A descriptive study was made between January and July of 2015 analyzing the parasitological tests of a population at a public hospital in Maceió-AL. Variables such as gender, age, positive tests, protozoan species, helminths species and parasitic associations were analyzed. Out of 1.581 tests, 806 (51\%) tested positive. Regarding gender, $535(67 \%)$ were from women. Helminths were the most predominant infections (63.94\%), compared to protozoans (36.06\%). The Helminths with the highest number of infections were: Ascaris lumbricoides (93.23\%), Trichuris trichiura (2.32\%) and Enterobius vermicularis (1.26\%). Among protozoans, Endolimax nana and Entamoeba coli corresponded to $78.09 \%$ and $15.91 \%$ respectively. Although non pathogenic, it suggests fecal contamination. According to the degree of parasitism, $84.0 \%$ were monoparasitism. It can be concluded that the number of positive tests for enteroparasites was high, mainly in men. The species A. lumbricoides was the main helminth detected, while E. nana was the main protozoan found in the tests. The age group between 24 and 59 years old was the one that had the highest amount of positive tests. The results observed strengthen the need for the implementation of prevention measures for intestinal parasitic infections.
\end{abstract}

KEYWORDS: Helminthiasis. Parasitic diseases. Protozoan infections.

\section{INTRODUCTION}

The intestinal parasitizes particularly in underdeveloped countries constitute itself as a major public health problem, these being caused by protozoa and helminths, and/or are quite widespread and with high prevalence, arising from the inadequate socio-sanitary conditions faced by poorer population layers (SOARES; OLIVEIRA; SOUZA, 2018).

Brazil has a great diversity of diseasecausing enteroparasites. This fact is associated with the geographical, climatic, social and economic conditions in the country. In the last 30 years, it has been observed in the country, a decrease in the prevalence of these parasites, however, in some regions infection rates are still close to $30.0 \%$, mainly the occurrence of monoparasitism (PRIETOPÉREZ et al., 2016).

These parasites cause pathologies that lead to high rates of morbidity and mortality (PARIJA; CHIDAMBARAM; MANDAL, 2017). The significant morbidity related to these diseases are often caused by poliparasitism sometimes associated with severe malnutrition and deprivation stages, with resulting synergism of aggravations and disastrous consequences to the individual (BACELAR et al., 2018).

The diagnosis of these diseases in laboratory routine is performed by parasitological examination of feces, being the one that can search the main parasitic structures. Occasionally, in some infections are observed other parasites that do not cause diseases but this becomes relevant because it reflects the contact with food and water, possibly contaminated, and thus present a higher probability of infection (HUMPHRIES et al., 2017).

Early detection can be done by identifying enteroparasites more common in the population, leading to enlightenment campaigns about the transmission mechanisms, prevention and treatment, especially in children and the elderly, which are the most affected groups of parasitic infections (THAMIZHMANI et al., 2017).

In Alagoas, there are few published works on the subject, though, they show that the high rate 
of prevalence of these diseases is due to the same factors that affect the poor people of any region of the world or the country. A reflection of this is seen in a parasitological study conducted with 67 residents belonging to 21 families that reside in a needy community in the municipality of Barra de Santo Antônio, AL, where it was observed that most of the houses were made of taipa (ROCHA et al., 2011), which can favor the spread of different enteroparasites. The low quality of life justified by socio-sanitary conditions observed in the community causes an increase in the prevalence of infection by intestinal parasites, as well as the existence of poliparasitism (ROCHA; BRAZ; CALHEIROS, 2010).

Thus, the objective of this study was to perform a retrospective study from January to July 2015, about the frequency of intestinal parasites in the population in a teaching Hospital, located in the municipality of Maceió-AL.

\section{MATERIALS AND METHODS}

This study was approved by the Research Ethics Committee (COEPE) of the Cesmac University Center, registered under the number: 44467015.8.0000.0039. We conducted a retrospective descriptive study, where 1.581 parasitologic feces results were analyzed, in the Laboratory of Clinical Analyses of University Hospital Alberto Antunes (HUPAA), located in the State of Alagoas, during the period from 01 January to 31 July 2015. The study used a census research, being included all the tests taken during the period studied.

Biological samples were received from patients made by medical requests. The tests were conducted by the qualitative method of sedimentation of Hoffman, Pons and Janer (HPJ). This method detects the presence of eggs and larvae of helminths and cysts of protozoa, being used in most clinical laboratories (GONÇALVES et al., 2016).

From the daily results, maps provided by the field of clinical analysis of the hospital data were obtained with the following variables: sex, age and the registration number of the patients who presented some type of parasitic infection and the correlation between the number of the total cases. Entamoeba histolytica/Entamoeba dispar, are not differentiated due to the fact the lab at the hospital not to make any distinction between these two species.

The samples were divided into seven age groups (for better understanding of the data and to check for possible correlations between the occurrence and age), as follows: 0 to 11 years; 12 to 23 years; 24 to 59 years and over 60 years. The data collected was inputed into the spreadsheet software Microsoft Office Excel $®$, version 2013, and analyzed descriptively and expressed in percentage.

\section{RESULTS AND DISCUSSION}

In the study period, out of 1.581 parasitologic feces examined, 806 (51.0\%) tested positive for one or more enteroparasites. In the present study, females presented 67.0\% (540) cases of parasitic infections, followed by males with $33 \%$ (266) of the cases. These findings corroborate with those described by Lima et al. (2020) where 32.4\% of the cases in a University Hospital in Santa CruzRN were from males, Melo et al. (2015) in the municipality of Bacabal-MA, where $63.8 \%$ of women were parasitized. Similarly, Ferreira et al. (2013) reported in a study the prevalence of infection of $65.4 \%$ among women, in the region of gravel pits in the municipality of Barreiras-BA and also by Sousa, Campos and Firmo (2020) finding a prevalence of $54 \%$ in females in the municipality of Alto Alegre do Pindaré-MA.

This higher frequency of infections in the female gender can be justified by the fact that women seek health services more often than men (MENEZES, 2013; OLIVEIRA FILHO et al., 2012). Inoue, Nigro and Castilho (2015) when evaluating the prevalence of intestinal parasitizes of patients in Irmandade da Santa Casa de Misericórdia de São Paulo, showing a prevalence of $63.7 \%$ among female patients.

In our study, out of the 806 positive tests, 473 tested positive for helminthiasis (63.94\%) and $333(36.06 \%)$ for protozoan infections. Table 1 shows the distribution of parasitism in relation to age group. Among children 0 to 11 years, 225 cases $(28.2 \%)$ were observed. The track between 12 to 23 years 126 cases $(15.6 \%)$ were observed. Between 24 and 35 years it was possible to identify 101 cases $(12.5 \%)$, and among patients with 36 to 47 years, 140 cases $(17.4 \%)$. Ranging in age from 48 to 59 years 112 cases $(13.9 \%)$ tested positive and between 60 and 71 years, 79 cases $(9.9 \%)$.

Drawing a parallel with the results obtained by other authors who performed this very same type of study in other states of the Northeast region, the prevalence of $51.0 \%$ positive intestinal parasites should be considered worrisome. In surveys conducted in João Pessoa-PB a prevalence of $69.0 \%$ could be found (OLIVEIRA; SILVA; MEDEIROS, 2014). In Buriti dos Lopes-PI the prevalence found 
was 41\% (SOUSA; COSTA; VIEIRA, 2018), in Estreito-MA (40.5\%) (FIRMO et al., 2011), Campina Grande-PB (30.7\%) and 12 in the municipality of Ibiassucê-BA (42.09\%) (MATOS; CRUZ, 2012). These studies show that the helminthiasis are still very prevalent, especially in country's poorest regions.

In regard to the age group, the one that presented the highest number of individuals who tested positive were between $0-11$ years. This same age group has been shown to be the most infected in other studies (ARAÚJO-FILHO et al., 2011; SOUZA et al., 2013). However, the above mentioned studies presented discordant results to Santos, Santos and Soares (2007) that observed that as the age increases, there is a progressive growth of frequency of parasitic infections.

Table 1. Absolute number and frequency (\%) of intestinal parasites spread by parasitological examination age in a population attended between January to July/2015 in a university hospital in the city of Maceió, AL, Brazil.

\begin{tabular}{llc}
\hline Age group & $\mathbf{N}^{\mathbf{0}}$ of patients & $\begin{array}{c}\text { Positivity rate by age } \\
\text { group (\%) }\end{array}$ \\
\hline $0-11$ & 225 & 28.2 \\
$12-23$ & 126 & 15.6 \\
$24-59$ & 353 & 43.8 \\
$>60$ & 102 & 12.8 \\
\hline Total & $\mathbf{8 0 6}$ & $\mathbf{1 0 0}$ \\
\hline
\end{tabular}

Our study showed parasitic infections by helminth to be $(63.94 \%)$. Results of similar works also reported rates of prevalence of helminths, as described by Marinho (2008) and Basso et al. (2008), with a prevalence of $28 \%$ and $65 \%$, respectively. On the other hand, the results of Menezes (2013) and Belo et al. (2012), displayed a pattern of high infection to Protozoan infections. The divergence of these results may be related to factors such as geographic area, socioeconomic status, nutritional status, age of the people who work and hygienic conditions (BELO et al., 2012). It was observed a predominance of parasitism occurred in people of the female gender with 535 cases $(66.0 \%)$ compared to male with 272 occurrences (34.0\%). Based on the results obtained, it should be noted that $63.94 \%$ of infections were caused by helminths, and $36.06 \%$ by protozoan.

Table 2 presents the distribution of species of enteroparasites detected in the samples analysed. Among helminths, Ascaris lumbricoides eggs were found (93.23\%), Trichuris trichiura (2.32\%), Enterobius vermicularis (1.26\%) followed by parasites of the family Ancylostomatidae (1.26\%). Among the protozoa, Endolimax nana cysts were found (78.09\%), Entamoeba coli (15.91\%) and lastly Giardia lamblia (4.80\%). 
Table 2. Distribution of species of enteroparasites found in a population between January to July/2015 in a university hospital in the city of Maceió (AL), Brazil.

\begin{tabular}{llc}
\hline Parasite & Occurrence & $\begin{array}{c}\text { \% (in relation to the total } \\
\text { amount of positive results) }\end{array}$ \\
\hline Helminths & $\mathbf{4 7 3}$ & $\mathbf{6 3 . 9 4}$ \\
\hline Ascaris lumbricoides & 441 & 93.23 \\
Trichuris trichiura & 11 & 2.32 \\
Enterobius vermicularis & 6 & 1.26 \\
Família Ancylostomatidae & 6 & 1.26 \\
Schistosoma mansoni & 5 & 1.05 \\
Strongyloides stercoralis & 3 & 0.63 \\
Hymenolepis nana & 1 & 0.25 \\
\hline Protozoan & $\mathbf{3 3 3}$ & $\mathbf{3 6 . 0 6}$ \\
\hline Endolimax nana & 260 & 78.09 \\
Entamoeba coli & 53 & 15.91 \\
Giardia lamblia & 16 & 4.80 \\
E. histolytica/E.dispar & 4 & 1.20 \\
\hline Total & $\mathbf{8 0 6}$ & $\mathbf{1 0 0}$ \\
\hline
\end{tabular}

* Percentage calculated according to the total number of samples that tested positive to one or more parasites

A. lumbricoides was the most prevalent helminth in this study with a rate of $93.23 \%$. Santos, Santos and Soares (2007) analyzing the occurrence of intestinal parasitizes in patients treated at the University Hospital Prof. Edgar Santos, Salvador$\mathrm{BA}$, found a rate of $35.2 \%$ for helminths; being the most frequent: A. lumbricoides $(5.8 \%)$, T. trichiura (4.2\%) and Ancylostomatidae (2.3\%), as in the present study. The high rate of $A$. lumbricoides is considered indicative of inadequate sanitation, commonly observed in urban and rural communities according to Menezes (2013). It is observed that A. lumbricoides is found in all age groups when viewed according to age distribution (Table 3). The A. lumbricoides infection is worrisome because the parasites in its larval stage can cause liver and pulmonary damage due to its migrations. And the adult stage can lead to intestinal damage due to mechanical destruction, malnourishment due to spoliation, toxic parasite antigen destruction and can even cause ectopic lesions in some infections (LAMBERTON; JOURDAN, 2015).

B. The S. stercoralis, presented a $0.63 \%$ frequency in the samples. This number may be underestimated, considering the low sensitivity and specificity of HPJ test for larvae, when compared to the Baermann-Mathew (1948), specific to this helminth. The same occurs with the low frequency of E. vermicularis, once the technique of Harada and Mori (1995) becomes less specific due to the parasitic cycle, since the female lays the eggs in the perianal region (FIRMO et al., 2011).

C. In relation to the protozoa, the species $E$. nana and $E$. coli showed more prevalent, however, they do not constitute serious harm to public health; but it serve as indicators of contamination by fecal-oral route, (MARZAGÃO et al., 2010). These results were similar to those demonstrated by Freitas et al. (2014), in a work done in Barra dos Garças-MT. Damaceno and Costa (2017) when evaluating the prevalence of enteroparasites in patients at a university hospital in Goiânia-GO, Brasil, detected that the occurrence of E. coli $(19 \%)$ and E. nana (3.1\%). And also by Inoue, Nigro and Castilho (2015), when it was identified Endolimax nana (46.6\%) and E. coli (43.3\%), in patients at a tertiary hospital with public appointments. 
Table 3. Percentage of positivity rates on the parasitological tests according to each age group done in patients between January and July/2015 at a university hospital in Maceió (AL).

\section{Percentage of positivity rates by age group}

\begin{tabular}{ccccc}
\hline Parasite & $\mathbf{0 - 1 1}$ & $\mathbf{1 2 - 2 3}$ & $\mathbf{2 4 - 5 9}$ & $>\mathbf{6 0}$ \\
\hline Helminths & & & \\
\hline Ascaris lumbricoides & $241(54.64 \%)$ & $150(34.01 \%)$ & $60(13.60 \%)$ & $30(6.80 \%)$ \\
Trichuris trichiura & $4(36.36 \%)$ & $4(36.36 \%)$ & $2(18.18 \%)$ & $1(9.09 \%)$ \\
Enterobius vermicularis & $3(50 \%)$ & $2(33.33 \%)$ & $1(16.66 \%)$ & - \\
Família & $2(33.33 \%)$ & $3(50 \%)$ & - & $1(16.67 \%)$ \\
Ancylostomatidae & $1(20 \%)$ & $2(40 \%)$ & $2(40 \%)$ & - \\
Schistosoma mansoni & - & $3(100 \%)$ & - & - \\
Strongyloides & - & $1(100 \%)$ & - & - \\
stercoralis & & & & \\
Hymenolepis nana & $109(41.92 \%)$ & $72(27.69 \%)$ & $65(25 \%)$ & $14(5.39 \%)$ \\
Protozoan & $25(47.16 \%)$ & $15(28.30 \%)$ & $7(13.20 \%)$ & $6(11.32 \%)$ \\
\hline Endolimax nana & $6(37.5 \%)$ & $(18.75 \%)$ & $4(25 \%)$ & $3(18.75 \%)$ \\
Entamoeba coli & - & $3(75 \%)$ & $1(25 \%)$ & - \\
Giardia lamblia & & 3 &
\end{tabular}

Intestinal species such as E. nana and $E$. coli, although considered non pathogenic, the rates should be worth noting, since it can be used as a parameter of fecal contamination that these patients are exposed to. (SANTOS; MERLINI, 2010).

In regards to the possible pathogenic action protozoan, E. histolytical E. dispar was found (1.20\%). According to Franco (2007) these protozoa emerged as one of the major public health problems in the last 25 years, being disseminated mainly by waterborne. Regarding the intensity of the parasitism, it was observed that the monoparasitism was more prevalent, with $84 \%$ (680) of the cases and the biparastism was equivalent to $14.0 \%$ (113), figure1.

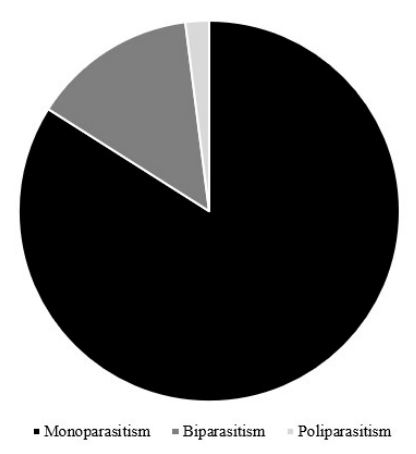

Figure 1. The distribution pattern of enteroparasites infection in a population attended between January to July/2015 in a university hospital in the city of Maceió, AL, Brazil. 
The last analysis undertaken was regarding the degree of poliparasitism, where the present study detected a high degree of monoparasitism (84.0\%). This result corroborates with a work done by Avelar (2012), in Paracatu-MG, where $79.96 \%$ of the samples analyzed pointed out to monoparasitism, while in $29.04 \%$ was found poliparasitism. On the other hand, our findings were different from those described by Andrade et al. (2011), in the Zona da Mata-MG, where 16 patients were diagnosed with multiple infections. The occurrence of poliparasitism can be explained by the fact that the basic sanitation conditions are poor, exposing the population to the acquisition of different enteroparasites (BUSCHINI et al., 2007).

\section{CONCLUSION}

It can be said that the positive rate of enteroparasites was very high, mainly in women. The most frequent helminth was the $A$. lumbricoides, found in all age groups analyzed. The rate of patients infected with protozoans was higher amongst $E$. nana and $E$. coli, species that indicate a fecal-oral contamination. The age group between 24 and 59 years old was the one that had the most amount of positive tests. The frequency of parasitized individuals is still great, demonstrating the need for improvements in planning actions aimed at the awareness of the population about the subject.

RESUMO: Os estudos da ocorrência de parasitoses em laboratório são de grande relevância, pois os mesmos podem proporcionar informações necessárias no diagnóstico da infecção e avaliar o índice de infecção parasitária, principalmente dos países em desenvolvimento, constituindo um problema de saúde pública. Foram coletados dados de exames de fezes realizados no período de janeiro a julho de 2015 nos registros de exames coproparasitológicos de fezes, de um hospital universitário de Maceió-AL. Foram analisados 1.581 exames, realizados pelo método de Hoffmann, Pons e Janer. Foi possível verificar que $51 \%$ apresentaram positividade para um ou mais enteroparasitos, sendo $66 \%$ para o sexo feminino e $34 \%$ no sexo masculino. Predominaram-se as infecções causadas por helmintos, com $55 \%$, seguido das infecções causadas por protozoários $45 \%$. Os helmintos com maior frequência de detecção foram: Ascaris lumbricoides (50,14\%), Trichuris trichiura $(1,61 \%)$, Enterobius vermicularis $(0,87 \%)$ e ancilostomídeos $(0,87 \%)$. Dentre os protozoários, Endolimax nana e Entamoeba coli com $34,42 \%$ e $7,8 \%$ respectivamente, que embora comensais indiquem contaminação fecal. A faixa etária entre 6 e 11 anos apresentou maior número de indivíduos parasitados $(2,1 \%)$. Quanto ao grau de parasitismo, houve uma predominância de $84 \%$ para monoparasitismo. Assim, conclui-se, que foi elevado o número positividade para enteroparasitos, com predominância de casos no gênero masculino. A espécie $A$. lumbricoides foi e helminto detectado, enquanto que, E. nana foi o principal protozoário. A faixa etária entre 6 a 11 anos foi a que apresentou maior número de casos positivos. Os resultados observados reforçam a necessidade da implantação de medidas de prevenção para as parasitoses intestinais.

PALAVRAS-CHAVE: Helmintíases. Infecções por protozoários. Parasitoses intestinais.

\section{REFERENCES}

ANDRADE, E. C.; LEITE, I. C. G.; VIEIRA, M. T.; ABRAMO, C.; TIBIRIÇA, S. H. C.; SILVA, P. L. Prevalência de parasitoses intestinais em comunidade quilombola no Município de Bias Fortes, Estado de Minas Gerais, Brasil, 2008. Epidemiologia e Serviços de Saúde. Revista do sistema Único de Saúde do Brasil, Brasília, v. 20, n. 3. p. 337-344, 2011. http://dx.doi.org/10.5123/S1679-49742011000300008.

ARAUJO-FILHO, H. B.; CARMO-RODRIGUES, M. S.; MELLO, C. S.; MELLI, L. C. F. L.; TAHAN, S.; MORAIS, M. B. Parasitoses intestinais se associam a menos índices de peso e estatura em escolares de baixo estrato socioeconômico. Revista Paulista de Pediatria, São Paulo, v. 29, n. 4, P. 521-528, 2011. https://doi.org/10.1590/S0103-05822011000400009.

AVELAR, I. A. Prevalência de parasitoses intestinais em crianças da escola municipal Pedro Silva Neiva, assentamento de Semterra (jambreiro), Paracatu (MG). 2012. 53 f. Trabalho de Conclusão de Curso (Graduação em Biomedicina) - Faculdade Tecsoma, Campina Grande, 2012. 
BACELAR, P. A. A.; SANTOS, J. P. D.; MONTEIRO, K. J. L.; CALEGAR, D. A.; NASCIMENTO, E. F. D.; CARVALHO-COSTA, F. A. Parasitoses intestinais e fatores associados no estado do Piauí: uma revisão integrativa. Revista Eletrônica Acervo Saúde, v. 10, n. 4, 1802-1809, 2018.

https://doi.org/10.25248/REAS223_2018

BASSO, R. M. C.; SILVA-RIBEIRO, R. T.; SOLIGO, D. S.; RIBACKI, S. I.; CALLEGARI-JACQUES, S. M.; ZOPPAS, B. C. A. Evolução da prevalência de parasitoses intestinais em escolares em Caxias do Sul, RS.

Revista da Sociedade Brasileira de Medicina Tropical, Uberaba, v. 41, n. 3, p. 263-268, 2008. https://doi.org/10.1590/S0037-86822008000300008

BELO, V. S.; OLIVEIRA, R. B.; FERNANDES, P. C.; NASCIMENTO, B. W. L.; FERNANDES, F. V.; CASTRO, C. F. L.; SANTOS, W. B.; SILVA, E. S. Fatores associados à ocorrência de parasitoses intestinais em uma população de crianças e adolescentes. Revista Paulista de Pediatria, São Paulo, v. 30, n. 2, p. 195-201, 2012. https://doi.org/10.1590/S0103-05822012000200007

BUSCHINI, M. L. T.; PITTNER, E.; CZERVINSK, T.; MORAES, I. F.; MOREIRA, M. M.; SANCHES, H. F.; MONTEIRO, M. C. Spatial distribution of enteroparasites among school children from Guarapuava, State of Paraná, Brazil. Revista Brasileira de Epidemiologia, São Paulo, v. 10, n.4, p.568-578, 2007. http://dx.doi.org/10.1590/S1415-790X2007000400015

DAMACENO, N. S.; COSTA, T. L. Incidência de enteroparasitoses em pacientes atendidos por um hospital universitário da cidade de Goiânia, GO, Brasil. Revista Brasileira de Análises Clínicas, v. 49, n. 2, p. 195 199, 2017.

FERREIRA, V. S.; LIMA, A. G. D.; PESSOA, C. S.; PAZ, F. S. S.; JESUS, J. Estudo comparativo das enteroparasitoses ocorrentes em duas áreas de Barreiras, Bahia. Natureza online, v. 11, n. 2, p. 90-95, 2013.

HUMPHRIES, D.; NGUYEN, S.; KUMAR, S.; QUAGRAINE, J. E.; OTCHERE, J.; HARRISON, L. M.; WILSON, M.; CAPPELLO, M. Effectiveness of Albendazole for hookworm varies widely by community and correlates with nutritional factors: a cross-sectional study of school-age children in Ghana. The American Journal of Tropical Medicine and Hygiene, v. 96, n. 2, p. 347-354, 2017. https://doi.org/10.4269/ajtmh.160682

INOUE, A. P.; NIGRO, S.; CASTILHO, V. L. P. Frequência de parasitas intestinais em um hospital terciário com atendimento SUS. Arquivos Médicos dos Hospitais e da Faculdade de Ciências Médicas da Santa Casa de São Paulo, v. 60, p. 7-11, 2015.

FIRMO, W. C. A.; MARTINS, N. B.; SOUSA, A. C.; COELHO, L. S.; FREITAS, M. S. Estudo comparativo da ocorrência de parasitos intestinais no serviço de saúde pública e privado de Estreito-MA. BioFar-Revista de Biologia e Farmácia, v. 5, n. 01, p. 85-93, 2011.

FRANCO, R. M. B. Protozoários de veiculação hídrica: relevância em saúde pública. Revista Panamericana de Infectologia, v. 9, n. 1, p. 36-43, 2007.

FREITAS, B. Q.; MESQUITA, M. J. S.; PERES NETO, N. J.; COSTA, K. A. S.; SCHERER, E. F.; OLIVEIRA, N. A. Levantamento dos principais parasitas presentes no município de Barra do Garças - Mato Grosso. Interdisciplinar: Revista Eletrônica da UNIVAR, Mato Grosso, v. 2, n. 12, p. 32-36, 2014.

GONÇALVES, S. A. A.; FERNANDES, H. M. B.; MEDEIROS, C. I. S.; OLIVEIRA FILHO, A. A. Perfil enteroparasitológico dos pacientes atendidos em uma policlínica do sertão da Paraíba, Brasil. Journal of Medicine and Health Promotion, Patos, v. 1, n. 3, p. 302-312, 2016.

HARADA, Y.; MORI, O. A new method for culturing hook-worm. Yonago Acta Medica, v. 1, n. 3, p.177-179, 1955. 
LAMBERTON, P. H. L.; JOURDAN, P. M. Human Ascariasis: Diagnostics Update. Current Tropical Medicine Reports, v. 2, n. 4, p. 189- 200, 2015. http://dx.doi.org/10.1007/s40475-015-0064-9

LIMA, E. C. S.; OLIVEIRA, H. M. B. F.; LEON, C. M. P.; BARBOSA, V. S. A. Prevalência de parasitoses intestinais em usuários de um hospital universitário, Santa Cruz-RN, Brasil. Revista de Atenção à Saúde, v. 18, n. 63, p. 21-30, 2020. http://dx.doi.org/10.13037/ras.vol18n63.6218

MARINHO, J. A. Prevalência das parasitoses intestinais e esquistossomose no município de Piau - Minas Gerais. 2008. 49 f. Monografia (Graduação em Farmácia) - Universidade Federal de Juiz de Fora, Minas Gerais, 2008.

MARZAGÃO, M.; ARAÚJO, W. R.; PACHECO, J. M. S.; BATISTA, M. C. S.; BUSATTI, H. G. N. O. Ocorrência de parasitoses intestinais em habitantes do município de Pará de Minas, MG - Brasil. Revista Brasileira de Farmácia, v. 91, n. 4, p. 183-8, 2010.

MATOS, M. A.; CRUZ, Z. V. Prevalência das parasitoses intestinais no município de Ibiassucê - Bahia. Revista Educação, Meio Ambiente e Saúde, Manhuaçu, v. 5, n. 1, p. 64-71, 2012.

MELO, A. R.; ERICEIRA, F. V.; OLIVEIRA, N. D.; ROCHA, J. R.; FIRMO, W. C. A. Ocorrência de parasitas intestinais em laudos parasitológicos de fezes de um laboratório privado do município de Bacabal-MA.

Enciclopédia Biosfera, Centro Cientifico conhecer, Goiânia, v. 11, n. 21, p. 3420-3430, 2015.

MENEZES, R. A. O. Caracterização epidemiológica das enteroparasitoses evidenciadas na população atendida na unidade básica de saúde Congós no município de Macapá - Amapá. 2013. 160 f. Dissertação (Mestrado em Ciência da Saúde) - Universidade Federal do Amapá, Macapá, 2013.

OLIVEIRA, W. B.; SILVA, R.; MEDEIROS, J. S. Enteroparasitos diagnosticados pelo método de sedimentação espontânea em um laboratório de análises clínicas. Journal of Biology \& Pharmacy and Agricultural Management, Campina Grande, v. 10, n. 4, p. 74-77, 2014.

OLIVEIRA FILHO, A. A.; ABRANTES, H. F. L.; FERNANDES, H. M. B.; VIANA, W. P.; PINTO, M. S. A.; CAVALCANTI, A. L.; FREITAS, F. I. S. Perfil enteroparasitológico dos habitantes de uma cidade do Nordeste do Brasil. Revista da Sociedade Brasileira de Clínica Médica, São Paulo, v. 10, n. 3, p. 179-182, 2012.

PARIJA, S. C.; CHIDAMBARAM, M.; MANDAL, J. Epidemiology and clinical features of soil-transmitted helminths. Tropical Parasitology, v. 7, n. 2, p. 81-85, 2017.

PRIETO-PÉREZ, L.; PÉREZ-TANOIRA, R.; CABELLO-ÚBEDA, A.; PETKOVA-SAIZ, E.; GÓRGOLASHERNÁNDEZ-MORA, M. Geohelmintos. Enfermedades Infecciosas y Microbiología Clínica, v. 34, n. 6, p. 384-389, 2016. http://dx.doi.org/10.1016/j.eimc.2016.02.002

ROCHA, T. J. M.; BRAZ, J. C.; CALHEIROS, C. M. L. Parasitismo intestinal em uma comunidade carente de Barra de Santo Antônio, Estado de Alagoas. Revista Eletrônica de Farmácia, Goiânia, v. 7, n. 3, p. 28-33, 2010. https://doi.org/10.5216/ref.v7i3.12893

ROCHA, T. J. M.; BRAZ, J. C.; SILVEIRA, L. J. D.; CALHEIROS, C. M. L. Relação entre aspectos socioeconômicos e a ocorrência de ectoparasitoses e enteroparasitoses em uma comunidade do litoral norte alagoano. Revista Brasileira de Análises Clínicas, Rio de Janeiro, v. 43, n. 4, p. 271-276, 2011.

SANTOS, L. P.; SANTOS, F. L. N.; SOARES, N. M. Prevalência de parasitoses intestinais em pacientes atendidos no Hospital Universitário Professor Edgar Santos, Salvador - Bahia. Revista de Patologia Tropical, Goiânia, v. 36, n. 3, p. 237-246. 2007. https://doi.org/10.5216/rpt.v36i3.3180 
SANTOS, S. A.; MERLINI, L. S. Prevalência de Enteroparasitoses na população do município de Maria Helena, Paraná. Revista Ciência \& Saúde Coletiva, v. 15, n. 3, p. 899-905, 2010.

https://doi.org/10.1590/S1413-81232010000300033

SOARES, A. L.; OLIVEIRA, E. A. N.; SOUZA, I. F. A. C. A importância da educação sanitária no controle e prevenção ao Ascaris lumbricoides na infância. Caderno de Graduação Ciências Biológicas e da SaúdeFACIPE, v. 3, n. 3, p. 22, 2018.

SOUSA, J. C. S.; CAMPOS, E. J. L. L.; FIRMO, W. C. A. Parasitas intestinais em pacientes atendidos em um laboratório público do município de Alto Alegre do Pindaré-MA. Journal of Biology \& Pharmacy

Agricultural Management, v. 16, n. 1, 2020.

SOUSA, A. C. P.; COSTA, L. N. G.; VIEIRA, J. M. S. Prevalência de enteroparasitas em indivíduos atendidos no Laboratório Municipal de Buriti dos Lopes, Piaú, Brasil. Revista Brasileira de Análises Clínicas, v. 50, n. 21, p. 84-88, 2018.

SOUZA, K. J.; TABOX, V. F.; OLIVEIRA, J. M. C.; PIEREZAN, M. R.; GIUFFRIDA, R.; BRESSA, R. C.; BRESSA, J. A. N. Perfil epidemiológico da anemia ferropriva no serviço de hematologia de um hospital público, estado de São Paulo, Brasil. Colloquium Vitae, v. 5, n. 1, p. 18-28, 2013.

http://dx.doi.org/10.5747/cv.2013.v005.n1.v072

THAMIZHMANI, R.; SUGUNAN, A. P.; RAGHVAN, P. R.; VIJAYACHARI, P. Intestinal parasitic infestation among paediatric diarrhoea patients attending hospitals in Port Blair, Andaman and Nicobar Islands. Journal of Parasitic Diseases, v. 41, n. 2, p. 584-589, 2017. https://doi.org/10.1007/s12639-016-0814-1 